\title{
TEACHERS MOTIVATION TOWARDS ASSESSMENT OF THEIR PROFESSIONAL COMPETENCES
}

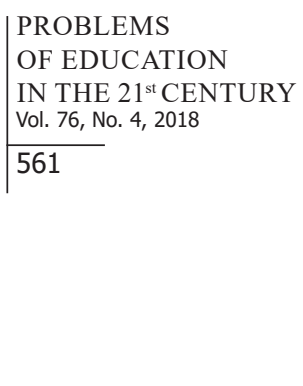

\author{
Eva Stranovská, Mária Lalinská, Ivana Boboňová \\ Constantine the Philosopher University, Slovakia \\ E-mail: estranovska@ukf.sk, mlalinska@ukf.sk, ibobonova@ukf.sk
}

\begin{abstract}
A relevant field of research in teacher's professional competence assessment is taking the factor of motivation into account, as this enables teachers to differentiate between, $i$. e. to be aware of the significance of the individual professional competences and their development through their assessment. This research supports the understanding of how important motivation is in the process of the (continual) development of a teacher's professional competence, taking his/her perception of the importance of competences in the educational process into account. The emphasis of the current research lays on the perception of the assessment by the selected number of primary and secondary school teachers. The following is the range of teacher's motivation perception: 1) motivating, 2) discouraging, 3) unnecessary, and 4) unfair in the process of life-long development of their professional competences. The research aim is to find out the differences in the individual motivational degrees in mutual assessment (motivating, discouraging, unnecessary, unfair, and other) relating to professional competences and find out the differences between the perception of the importance of the respective professional competences in the motivational category. Seven hundred thirty respondents - primary and secondary school teachers from Slovakia - participated in the research. The results showed the difference between the perception of the importance of professional competences among teachers who consider assessment to be motivating, discouraging, unnecessary, or unfair concept. Motivation towards assessment supports student-oriented competences, educational process and self-development of the teacher.
\end{abstract}

Keywords: educational process, teacher competences assessment, teachers' motivation, teachers' professional competences.

\section{Introduction}

The assessment of a teacher's professional competences as one of the crucial indicators of the quality of the educational process influences not only the quality of a teacher's way of thinking, their professional growth but the performance and education of the students in particular. Liepa, Dudkina \& Sile (2012); Rodriguez-Campos \& Mitchell (2015) consider teacher evaluations for a vital component of a continuous improvement process that can if administered correctly, help with the ultimate goal of getting students to be successful. As long as the teachers don't find the assessment motivating, the assessment itself has no significance. Motivation is, by many, considered an important factor for teacher's professional development (Recepoğlu, 2013). Nowadays, research in the field of teacher assessment is present only to a small extent. Mostly, it focuses on competence assessment tools design and their standardization (Gadusova \& Haskova, 2016; Gold \& Holodynski, 2015; González \& López, 2010; Lukas, Santiago, Etxeberria \& Lizasoain, 2014; Moreno-Murcia, Torregrosa \& Pedreno, 2015). Several research studies in the field of teachers' competences emphasized either standardization of professional competences (Pavlov, 2013) or professional assessment (De Wever, Vanderlinde, Tuytens \& Aelterman, 2016; European Commision, 2012; Kuhn, Alonzo \& Zlatkin-Troitschanskaia, 2016; Schleicher, 2012; Svarbova, 2012 and others) or education quality measurements (Blömeke et al., 2011; Fritsch et al., 2015; Kleickmann et al., 2013; Sarnikova, 2010). 
Eva STRANOVSKÁ, Mária LALINSKÁ, Ivana BOBOŇOVÁ. Teachers motivation towards assessment of their professional competences

PROBLEMS

OF EDUCATION

IN THE $21^{\text {st }}$ CENTURY

Vol. 76, No. 4, 2018

562

Even though the contemporary research focuses on teacher's competence training and assessment, it doesn't involve the teacher's perception of their competence assessment. It is important that the teachers perceive their assessment as motivating, as a motivating assessment of the teacher from their superiors influences the teacher's personal and professional growth as well as the successfulness in the education process and self-efficacy. Motivation can be considered, towards assessment, as a key moment in the work of a teacher, as it can help the teacher to differentiate and be aware of the significance of the respective professional competences. Presumably, if the assessment done by the superior teachers motivates the teacher, then they differentiate their individual professional competences and capabilities, use them in the education process adequately, and thus increase the quality of education.

In the current research, the motivation of the teacher connected to their assessment related to the degree of motivation and professional competence is examined, i. e. in which motivational degree is the scope of awareness about professional competences significantly different and which specific professional competence is deemed to be important in the assessment by a motivated teacher.

The research aim is to find out the differences in the individual motivational degrees in mutual assessment (motivating, discouraging, unnecessary, unfair, and other) relating to professional competences and find out the differences between the perception of the importance of the respective professional competences in the motivational category.

The research presents a partial task of the APVV 14_0446 Hodnotenie kompetencii učitel'a [Assessment of teacher's competences] research project (Ceretkova, Bobonova, Markechova \& Tirpakova, 2016; Fandelova, Gadusova \& Lomnicky, 2016; Gadusova \& Haskova, 2016; Gadusova, Hockickova, Lomnicky, Predanocyova \& Zilova, 2016; Gadusova \& Viteckova, 2015; Magova et al., 2016; Stranovska, Lalinska \& Bobonova, 2017), in which it is analysed the issues connected to the teacher's professional competence assessment in European and Slovak context and the perception of oral and written assessment of a teacher's professional competence by both assessors and teachers; the works furthermore explore the assessment of teacher's competences in relation to variables such as time spent in practice, specialization, assessment skills of the assessor and others.

\section{Teacher Competences Assessment}

Assessment of teachers associated with self-assessment refers to the motivation of the teachers themselves to monitor and assess their performance and change its quality through continuous reflection and education. Sarnikova (2010), Pavlov (2013) and Gold \& Holodynski (2015) defined several dominating factors determining the structure of teacher competences in the assessment process. They were: the (1) aspect of undergraduate education (its content and the graduate profile), (2) special context of educational situations, (3) teacher as an autonomous entity, or to a personal orientation in its dynamic meaning, referring to both, teachers and pupils developments, and (4) requirements of developing society from different points of views, for example, family, region, national or international community.

Assessment and diagnosis of teacher competences, as Sokolova, Lemesova \& Zacharova (2014) state, pursues several objectives - research of competences, diagnostics of competences and self-evaluation process. Although the prerequisites of the objectives are valid and reliable methods and tools of teacher competency assessment, to assess their levels can be difficult for several reasons (Frey, 2006; Philpott, Scott \& Mercier, 2014; Sokolova et al., 2014). Difficulties include: definitions and indicators of different responsibilities not clearly defined, the use of different experts and different educational concepts from a variety of competence models, and putting emphasis on different areas of competence. Different tools for assessing competences usually cover only one content category or only one component of such competence. Thus, the competence profile of the teacher is then, reduced and distorted. Moreover, quantitative tools, mainly questionnaires, prevail, which, similarly, limit the process and increase the risk 
of generalizing, i.e. the tools classify teacher' competences, but do not consider individual characteristics and abilities of teachers, and they often fail to capture the process of their changes.

Assessment of teachers, as viewed by Gadusova and Haskova (2016), performs several functions. First, diagnostic function observes the actual professional performance of the teacher. Second, comparative function involves comparisons of his/her professional performance with other professionals in order to follow their own self-development in the direction of acquiring new experiences. Third, stimulatory function refers to teacher's career promotion, which depends on assessment. Fourth, corrective function serves as a basis for self-correction of teacher's activities and motivates them to seek ways to improve their performance. Then, judging function refers to the ways of remunerations, whether in the form of transaction, material, or relational intangible benefits, that are based on the assessment results. Educational covers assessment that forms the personality of the evaluated person in long-terms and, finally, social function, the results of assessment help to shape social status of teachers, have an impact on the growth of their professional self-confidence and ensure the satisfaction of their need for self-realization.

Teachers, who are motivated towards systematic self-reflection of their educational activities and their evaluation, are able to design their own educational future and can set their own personal development goals, for example, they are willing to take an innovative and progressive role, are willing to be involved in continuous education and so on. There have been many factors evaluated; therefore, motivation towards assessment was considered crucial in the research study.

\section{Process of Motivation and Perception of Teacher's Professional Development}

The motivational process determines direction and intensity of behaviour of the individual in the broadest sense. Teacher motivation towards assessment of their professional competences relates to their perception of success or failure in the assessment, as well as to their perception of the importance of their professional self-development. Investigation of the attribution of success and failure and examining of individuals explain their success and failure. It is the subject of attribution theory. Various aspects of the process are examined at different levels of research. Kirchner (2004) defines the most important attributions as follows: a) individual's sole responsibility for their own success or failure, b) whether the individual considers the cause of their success or failure to be stable or unstable, c) whether the individual takes control of any changes themselves or leaves it to others. According to attribution theory individual creates their convictions of success or failure, which affect their behaviour, or their motivation to act. Generally, motivation is not examined in isolation. Dörnyei (2014) highlights the close interaction of motivation with emotions and cognition. Earlier concepts of motivation emphasized intra psychic dimension, which determines the quality of motivation. Gardner (1985) defines two types of motivation: integrative and instrumental. In the process of teacher's motivation, thus, an individual goal, meaning and purpose of the educational process played an important role. In this context, however, it is questionable how important for the teacher success, with respect to the assessment of their professional competences, has the desired goal or state that they want to achieve. The latest theoretical models, therefore, seek to integrate previous motivational theories and understand the complexity of motivation (Dörnyei, 2014; Riemer, 2010 and others). These models are usually multidimensional and observe the interaction among different internal and external dimensions of motivation. Noteworthy is also the current theory, so-called the hypotheses of the individual (Dörnyei, 2014; Riemer, 2010), which belongs to the current trends of research in the field of motivation and its predictors. It distinguishes the causal hypothesis and resultative hypothesis. Causal hypothesis postulates that motivation should lead individuals to success. Resultative hypothesis assumes that success can lead an individual to motivation. This synergy of motivation and success is not yet clarified whether the variable of motivation predicts success or vice versa. 
Eva STRANOVSKÁ, Mária LALINSKÁ, Ivana BOBOŇOVÁ. Teachers motivation towards assessment of their professional competences

PROBLEMS

OF EDUCATION

IN THE $21^{\text {st }}$ CENTURY

Vol. 76, No. 4, 2018

564

In the context of the given research, it is paid more attention to the resultative hypothesis. If teachers experience positive feedback in the process of the first evaluation by head teacher, they see the assessment of their professional competences as motivating. If the assessment of professional competences is perceived as motivating, they attribute significance and importance to professional competences in the educational process. What's further explored is, when does a teacher perceive the assessment to be motivating, which professional competences in the educational process does he/she ascribe significance and importance to so as to succeed in pedagogical activity.

\section{Research Methodology}

\section{General Background}

In this research is focused on the partial results of the four-year research project APVV14-0446 Evaluation of teacher competences which is oriented on the development of suitable tools for evaluation of teachers' professional competences in the Slovak educational context. In the Slovak educational context, the tools for measuring teachers' professional competencies are not developed yet. In order to develop these tools, it is necessary to take into account several factors arising from the current status of teacher evaluation and educational reality at different levels of the Slovak education system from the point of view of both the evaluator and the evaluated one. One of these key factors is the teacher's motivation to assess his/her competences. The research started in 2015.

This research dealt with the statistical processing of the data related to the degree of motivation for assessment and perception of the degree of importance of different professional competences. The motivational aspect of the teachers' assessment by their authorities with respect to the level of importance of different professional competences of teachers was the main focus of the research. Statistical processing of the other variables was the subject of research studies to which the current study refers. The motivation towards assessment by authorities was divided into the following five degrees: motivating (M), discouraging (D), unnecessary (UN), unfair (UF), other (O).

Based on the selected levels in processing, the data obtained, the respondents, were divided into five groups. Group $\mathbf{M}$ represented teachers who perceived assessment by their authorities as motivating. Similarly, group D referred to teachers, for whom the assessment was discouraging. Group $\mathbf{U N}$ viewed assessment as unnecessary; UF as unfair, and $\mathbf{O}$ stated other attributes of the assessment when considering its motivating aspect.

Perception of the level of importance of professional competences of teachers was rated 1 through $5(1=$ low importance, $5=$ very high importance $)$ while the following competences were taken into account:
A. can identify students' developmental and individual characteristics;
B. can identify psychological and social factors of student's learning;
C. can assist in the development of student's personality and their competences;
D. can create a positive climate in the classroom;
E. can plan and implement their own career enhancement;
F. is well aware of the content and methodology of the subjects taught;
G. can plan and design teaching / educational process;
$\mathrm{H}$. is able to select and implement teaching forms and methods;
I. is able to use teaching materials and aids in teaching process;
J. can evaluate the progress and results of teaching and students learning. 
Hypothesis: Based on the selected group identification ranging from $\mathrm{M}-\mathrm{O}$ (according to the degree of motivation), the teachers perceive differences in the degree of importance in motivation towards assessment of their own professional competences carried out by the authorities. ${ }^{1}$ The expected assumptions are significant differences in the competences marked as A, B, C, E. ${ }^{2}$

The stated research hypothesis functioned based on the variety of variables. The first (onedimensional) variable was considered to be the level of the degree of importance of the listed professional competences ranging from $1-5$. The second variable of the set research hypothesis was two-dimensional, namely, the level of motivation of teachers towards assessment by an authority, groups of $\mathrm{M}, \mathrm{D}, \mathrm{UN}, \mathrm{UF}$ or $\mathrm{O}$. The groups were mutually compared: M-D, M-UN, M-UF, M-O, D-UN, D-UF, D-O, UN-UF, UN-O, and UF-O.

\section{Instruments and Procedure}

The perception of teachers' motivation to assessing their professional competences by their authorities and the degree of importance of their professional competences in the educational process was implemented in the research study using the Questionnaire for teacher competences assessment developed for teachers. The questionnaire was a primary tool to measure teachers' motivation for assessing their professional competences and the importance of different professional competences of teachers in the Slovak educational context. The questionnaire consisted of 11 questions. It was focused on finding the data on the extent to which teachers' professional competences are important in terms of the success of their teaching activity, ways and course of teacher evaluation. Based on the first question the respondents were divided into groups according to the degree of motivation (motivating, discouraging, unnecessary, unfair, other). Consequently the other questions were used to classify teachers according to the perception of the degree of importance of the individual competencies mentioned in the section General Background.

\section{Research Sample}

The questionnaire was administered anonymously, to 730 respondents from primary and secondary schools in the period between September 2015 and January 2016. The respondents were chosen by the way of random selection with the condition of the affiliation with the region. Each region was proportionally represented in research (Bratislava, Trnava, Nitra, Banská Bystrica, Trenčín, Žilina, Prešov, Košice). Several attributes related to members of the research sample were tracked in the research (teacher's gender, number of years of teaching at the school, subjects taught, teacher's affiliation to the type of school, and others) as it can be seen at table 1 .

$1 \quad$ It is assumed that the research study examining the current subject has not been carried out in a global scale yet. In the Slovak Republic, such research was conducted under the auspices of the State Institute for Education in Bratislava. It surveyed the views of teachers and head teachers on educational innovations. In the course of this research project the research showed teachers' considerations of the need to innovate strategies and methods to be the most important. In the current research comparison of different perspectives of teachers on motivation towards their assessment by their authorities, with regards to, their perceptions of the importance of different professional competences in the educational process were investigated (Bagalová, 2011).

2 Currently the increased interest of teachers in workshops developing just the competences associated with the ability to identify the developmental and individual characteristics of learners, identify psychological and social factors of student's learning, develop student's personality and their competences, plan and implement own professional development can be observed. Approach of teachers, who perceive these competences as important, is assumed to be in the light of the current educational trends as still relevant and needed. 
Eva STRANOVSKÁ, Mária LALINSKÁ, Ivana BOBOŇOVÁ. Teachers motivation towards assessment of their professional competences

PROBLEMS

OF EDUCATION

IN THE $21^{\text {st }}$ CENTURY

Vol. 76, No. 4,2018

566

\section{Table 1. Description of research sample.}

\begin{tabular}{ll} 
Gender & 133 males and 597 females \\
\hline Number of years of teaching at the school & $\begin{array}{l}59 \text { respondents less than } 5 \text { years, } 115 \text { respondents from } 5 \text { up to } 10 \\
\text { years, } 253 \text { respondents from } 11 \text { up to } 20 \text { years, } 303 \text { respondents from } \\
\text { more than } 21 \text { years }\end{array}$ \\
\hline Completed teacher formation & $\begin{array}{l}534 \text { secondary school teachers, } 145 \text { primary school teachers, } 51 \text { non- } \\
\text { pedagogical formation }\end{array}$ \\
\hline Kind of school & $\begin{array}{l}142 \text { primary school teachers, 323 lower secondary school teachers, } \\
265 \text { upper secondary school teachers }\end{array}$ \\
\hline
\end{tabular}

\section{Data Analysis}

The descriptive statistics was used for the purpose of the statistical processing and the analysis of the collected data. The focus is laid on the description of basic statistical indicators (mean, minimum, maximum, median, mode, skewness and kurtosis).

The Friedman test and Man-Whitney U-test were used to examine if significant differences had been observed in the perception of the extent of importance of professional competences among groups of teachers with regard to their level of motivation towards assessment by their authorities. Moreover, the following tools were used to explore the significance in the perception of motivation $\mathrm{M}-\mathrm{O}$ : Friedman test was used in the first phase to determine the existence of differences and Man-Whitney U-test was used to identify significant differences in perception of the extent of the importance of individual competencies regarding the degree of teacher's motivation towards assessment.

They were characteristics of the degree of symmetry in the distribution of the frequency of the observed aspect - the obtained point of assessment of the different competences associated with the groups ranging from $M-O$, in comparison with the normal distribution. Kurtosis refers to the characteristics of the degree of flattening/sharpness frequency distribution of the feature - the obtained point evaluation of the different competences referring to the groups $M-O$, in comparison with the standard distribution).

\section{Results of Research}

Table 2 illustrates the results of descriptive statistics of different competences of teachers, depending on the variable associated with the degree of motivation of teachers towards the assessment by an authority, or group of motivation perception, referring to $M-O$. 
Table 2. Descriptive statistics of the degree of motivation of teachers towards assessment and the degree of importance of professional competences.

\begin{tabular}{|c|c|c|c|c|c|c|c|c|c|c|c|}
\hline \multicolumn{2}{|c|}{$\begin{array}{l}\text { Professional compe- } \\
\text { tence }\end{array}$} & \multirow{2}{*}{$\begin{array}{l}\text { A } \\
4.37 \\
1 \\
5 \\
5 \\
5 \\
.643\end{array}$} & \multirow{2}{*}{$\begin{array}{l}\text { B } \\
4.30 \\
1 \\
5 \\
4 \\
5 \\
.576\end{array}$} & \multirow{2}{*}{$\begin{array}{l}\text { C } \\
4.63 \\
1 \\
5 \\
5 \\
5 \\
.397\end{array}$} & \multirow{2}{*}{$\begin{array}{l}\mathrm{D} \\
4.71 \\
1 \\
5 \\
5 \\
5 \\
.346\end{array}$} & \multirow{2}{*}{$\begin{array}{l}\mathrm{E} \\
4.16 \\
1 \\
5 \\
4 \\
5 \\
.758\end{array}$} & \multirow{2}{*}{$\begin{array}{l}\mathrm{F} \\
4.74 \\
1 \\
5 \\
5 \\
5 \\
.330\end{array}$} & \multirow{2}{*}{$\begin{array}{l}G \\
4.65 \\
1 \\
5 \\
5 \\
5 \\
.402\end{array}$} & \multirow{2}{*}{$\begin{array}{l}\mathrm{H} \\
4.61 \\
1 \\
5 \\
5 \\
5 \\
.422\end{array}$} & \multirow{2}{*}{$\begin{array}{l}\text { I } \\
4.28 \\
1 \\
5 \\
4 \\
4 \\
.574\end{array}$} & \multirow{2}{*}{$\begin{array}{l}\mathrm{J} \\
4.65 \\
1 \\
5 \\
5 \\
5 \\
.439\end{array}$} \\
\hline \multirow{4}{*}{$\begin{array}{l}M \\
(538)\end{array}$} & $\begin{array}{l}\text { Average } \\
\text { Minimum } \\
\text { Maximum } \\
\text { Median } \\
\text { Mode } \\
\text { Variance }\end{array}$ & & & & & & & & & & \\
\hline & $\begin{array}{l}\text { Standard } \\
\text { deviation }\end{array}$ & .802 & .759 & .630 & .588 & .870 & .574 & .634 & .649 & .758 & .663 \\
\hline & $\begin{array}{l}\text { Skew- } \\
\text { ness }\end{array}$ & -1.2 & -0.95 & -2.07 & -2.81 & -.90 & -2.83 & -2.38 & -2.02 & -1.06 & -2.63 \\
\hline & Kurtosis & 1.09 & .85 & 6.05 & 10.95 & .746 & 10.69 & 7.97 & 5.67 & 1.56 & 9.46 \\
\hline \multirow{3}{*}{$\begin{array}{l}\text { Group } \\
D \\
(16)\end{array}$} & $\begin{array}{l}\text { Average } \\
\text { Minimum } \\
\text { Maximum } \\
\text { Median } \\
\text { Mode } \\
\text { Variance }\end{array}$ & $\begin{array}{l}4.13 \\
2 \\
5 \\
4 \\
4 \\
.783\end{array}$ & $\begin{array}{l}4.00 \\
2 \\
5 \\
4 \\
4 \\
.800\end{array}$ & $\begin{array}{l}4.38 \\
3 \\
5 \\
5 \\
5 \\
.650\end{array}$ & $\begin{array}{l}4.81 \\
4 \\
5 \\
5 \\
5 \\
.163\end{array}$ & $\begin{array}{l}4.19 \\
2 \\
5 \\
4 \\
5 \\
.829\end{array}$ & $\begin{array}{l}.75 \\
3 \\
5 \\
5 \\
5 \\
.333\end{array}$ & $\begin{array}{l}4.69 \\
3 \\
5 \\
5 \\
5 \\
.363\end{array}$ & $\begin{array}{l}4.50 \\
3 \\
5 \\
5 \\
5 \\
.400\end{array}$ & $\begin{array}{l}4.31 \\
3 \\
5 \\
4 \\
4 \\
.363\end{array}$ & $\begin{array}{l}.63 \\
3 \\
5 \\
5 \\
5 \\
.383\end{array}$ \\
\hline & $\begin{array}{l}\text { Standard } \\
\text { deviation }\end{array}$ & .885 & .894 & .806 & .403 & .911 & .577 & .602 & .632 & .602 & .619 \\
\hline & $\begin{array}{l}\text { Skew- } \\
\text { ness }\end{array}$ & -.93 & -.639 & -.845 & -1.77 & -1.02 & -2.38 & -1.89 & -.90 & -.21 & -1.51 \\
\hline \multirow{4}{*}{$\begin{array}{l}\text { Group } \\
\text { UN } \\
(57)\end{array}$} & $\begin{array}{l}\text { Kurtosis } \\
\text { Average } \\
\text { Minimum } \\
\text { Maximum } \\
\text { Median } \\
\text { Mode } \\
\text { Variance }\end{array}$ & $\begin{array}{l}.694 \\
4.26 \\
2 \\
5 \\
4 \\
5 \\
.697\end{array}$ & $\begin{array}{l}.027 \\
3.98 \\
2 \\
5 \\
4 \\
4 \\
.803\end{array}$ & $\begin{array}{l}-.84 \\
4.46 \\
1 \\
5 \\
5 \\
5 \\
.717\end{array}$ & $\begin{array}{l}1.285 \\
4.68 \\
3 \\
5 \\
5 \\
5 \\
.327\end{array}$ & $\begin{array}{l}.629 \\
3.91 \\
1 \\
5 \\
4 \\
4 \\
.760\end{array}$ & $\begin{array}{l}5.314 \\
4.51 \\
2 \\
5 \\
5 \\
5 \\
.540\end{array}$ & $\begin{array}{l}3.035 \\
4.58 \\
2 \\
5 \\
5 \\
5 \\
.498\end{array}$ & $\begin{array}{l}.027 \\
4.49 \\
2 \\
5 \\
5 \\
5 \\
.504\end{array}$ & $\begin{array}{l}-.38 \\
4.18 \\
2 \\
5 \\
4 \\
4 \\
.504\end{array}$ & $\begin{array}{l}1.580 \\
4.65 \\
3 \\
5 \\
5 \\
5 \\
.268\end{array}$ \\
\hline & $\begin{array}{l}\text { Standard } \\
\text { deviation }\end{array}$ & .835 & .896 & .847 & .572 & .872 & .735 & .706 & .710 & .710 & .517 \\
\hline & $\begin{array}{l}\text { Skew- } \\
\text { ness }\end{array}$ & -.92 & -.58 & -1.78 & -1.67 & -.66 & -1.43 & -1.71 & -1.36 & -.58 & -1.04 \\
\hline & & .138 & -.35 & 3.713 & 1.884 & .848 & 1.508 & 2.583 & 1.647 & .315 & -.07 \\
\hline \multirow{3}{*}{$\begin{array}{l}\text { Group } \\
\text { UF } \\
(33)\end{array}$} & $\begin{array}{l}\text { Average } \\
\text { Minimum } \\
\text { Maximum } \\
\text { Median } \\
\text { Mode } \\
\text { Variance }\end{array}$ & $\begin{array}{l}4.18 \\
1 \\
5 \\
4 \\
4 \\
.778\end{array}$ & $\begin{array}{l}3.97 \\
1 \\
5 \\
4 \\
4 \\
.780\end{array}$ & $\begin{array}{l}5 \\
.633\end{array}$ & $\begin{array}{l}4.58 \\
2 \\
5 \\
5 \\
5 \\
.564\end{array}$ & $\begin{array}{l}4.06 \\
1 \\
5 \\
4 \\
5 \\
.996\end{array}$ & $\begin{array}{l}5 \\
5 \\
.354\end{array}$ & $\begin{array}{l}4.30 \\
3 \\
5 \\
4 \\
4 \\
.468\end{array}$ & $\begin{array}{l}5 \\
5 \\
.508\end{array}$ & $\begin{array}{l}4 \\
5 \\
.653\end{array}$ & $\begin{array}{l}4.64 \\
3 \\
5 \\
5 \\
5 \\
.301\end{array}$ \\
\hline & $\begin{array}{l}\text { Standard } \\
\text { deviation }\end{array}$ & .882 & .883 & .795 & .751 & .998 & .595 & .684 & .712 & .808 & .549 \\
\hline & Skew- & -1.54 & -1.09 & -1.64 & -1.92 & -.93 & -1.65 & -.47 & -1.05 & -.35 & -1.19 \\
\hline \multirow{4}{*}{$\begin{array}{c}\text { Group } \\
0 \\
(86)\end{array}$} & $\begin{array}{l}\text { Kurtosis } \\
\text { Average } \\
\text { Minimum } \\
\text { Maximum } \\
\text { Median } \\
\text { Mode } \\
\text { Variance }\end{array}$ & $\begin{array}{l}4 \\
4 \\
.768\end{array}$ & $\begin{array}{l}2.524 \\
4.00 \\
1 \\
5 \\
4 \\
4 \\
.847\end{array}$ & $\begin{array}{l}5 \\
5 \\
.569\end{array}$ & $\begin{array}{l}3.545 \\
4.64 \\
2 \\
5 \\
5 \\
5 \\
.492\end{array}$ & $\begin{array}{l}.877 \\
3.92 \\
1 \\
5 \\
4 \\
4 \\
1.017\end{array}$ & $\begin{array}{l}5 \\
5 \\
.503\end{array}$ & $\begin{array}{l}-.73 \\
4.62 \\
3 \\
5 \\
5 \\
5 \\
.333\end{array}$ & $\begin{array}{l}5 \\
5 \\
.413\end{array}$ & $\begin{array}{l}-1.37 \\
4.13 \\
2 \\
5 \\
4 \\
4 \\
.678\end{array}$ & $\begin{array}{l}.519 \\
4.56 \\
3 \\
5 \\
5 \\
5 \\
.367\end{array}$ \\
\hline & $\begin{array}{l}\text { Standard } \\
\text { deviation }\end{array}$ & .876 & .920 & .754 & .701 & 1.008 & .709 & .577 & .642 & .823 & .606 \\
\hline & Skew- & -.83 & -.65 & -2.43 & -2.08 & -89 & -2.26 & -1.22 & -1.22 & -.63 & -1.04 \\
\hline & Kurtosis & .658 & .058 & 6.873 & 4.024 & .687 & 7.025 & .542 & .363 & -.24 & .095 \\
\hline
\end{tabular}

Degree of motivation: $\mathrm{M}$ - motivating, D - discouraging, UN - unnecessary, UF - unfair, O - other. 
Eva STRANOVSKÁ, Mária LALINSKÁ, Ivana BOBOŇOVÁ. Teachers motivation towards assessment of their professional competences

PROBLEMS

OF EDUCATION

IN THE $21^{\text {st }}$ CENTURY

Vol. 76, No. 4, 2018

The highest score of the competence $\mathrm{F}$ was found in the group $M$ (motivated teachers) is well aware of the content and methodology of the subjects taught (mean 4.73). This competence received the highest rating also in the group $N$ (mean 4.67). In the group $D$, the highest rated competence was D can create a positive climate in the classroom (mean 4.81), similarly as in the group $U N$ (mean 4.68). The teachers from the group $\mathrm{O}$ (mean 4.64) considered the last competence as the most important, also.

The option E. can plan and implement their own career development has reached the lowest mean in the groups $M, U N, O$. The groups $D$ and $U F$ consider B. can identify the psychological and social factors of student's learning, to be the least important professional competence.

The observed order of frequency options of competences was confirmed also by the median values for the selected responses in different groups $M-O$. To verify the hypothesis, Friedman test and Wilcoxon test (Mann-Whitney U-test) was applied. Friedman test was used in order to determine the existence of differences in the perception of the importance of professional competences based on their groups $M-O$ selection. The key question whether there is a difference in the category motivating versus other categories (discouraging, unnecessary, unfair, other) of teacher assessment by their authorities and the importance of which professional competences have an impact on the degree of motivation for assessment was examined. The tool compared a number of core sets based on the dependent selection sets. At the same time, there was no need to fulfil the presumption of the normal distribution of basic sets. Due to this fact the null hypothesis $\mathrm{H} 0$ (the degree of perception of the importance of professional competences by teachers in the group $x^{3}$ and the group $y^{4}$ was the same), and the alternative hypothesis $\mathrm{H}_{1}$ (the degree of perception of the importance of professional competences by teachers in the group $x$ and the group $y$ was different) were set. Based on the evaluation of the collected data using SPSS software, the tested hypothesis $\mathrm{H}_{0}$ was rejected at the significance level $\alpha=.001(* * *)$ in favor of the alternative hypothesis $\mathrm{H}_{1}$. The degree of perception of the importance of professional competences of teachers in the given groups was therefore different. The results were presented in Table 2. Furthermore, the investigation followed in comparison of different groups according to the degree of motivation $M-O$, but also in comparison of the group of teachers motivated towards assessment (group $M$ ) and other teachers (group $D, U N$, $U F, O$ ). The results obtained by Friedman's test were displayed in Table 3.

Table 3. Statistical parameters according to Friedman's test - the existence of differences in the degree of importance of professional competences in relation to the degree of teacher's motivation for the evaluation by their superior (groups $M-O$ ).

\begin{tabular}{lcccccccccc}
\hline $\begin{array}{l}\text { Compared } \\
\text { groups } x / y\end{array}$ & M/D & M/UN & M/UF & M/O & D/UN & D/UF & D/O & UN/UF & UN/O & UF/O \\
\hline $\mathrm{N}$ & 554 & 595 & 571 & 624 & 73 & 49 & 102 & 90 & 143 & 119 \\
\hline$X^{2}$ & 2584.11 & 2722.68 & 2506.69 & 2136.28 & 304.863 & 117.947 & 195.495 & 264.783 & 235.316 & 212.103 \\
\hline $\mathrm{df}$ & 10 & 10 & 10 & 10 & 10 & 10 & 10 & 10 & 10 & 10 \\
\hline
\end{tabular}

p $\quad .0001^{* * *} .0001^{* * *} \quad .0001^{* * *} .0001^{* * *} .0001^{* * *} \quad .0001^{* * *} \quad .0001^{* * *} \quad .0001^{* * *} \quad .0001^{* * *} \quad .0001^{* * *}$

Statistical significance at the level $\alpha=.001(* * *)$

3 Under the variable $\mathrm{x}$ is understood the group $M-O$ with respect to the degree of teachers' motivation for evaluation.

4 Under the variable $\mathrm{x}$ is understood the group $M-O$ with respect to the degree of teachers' motivation for evaluation. 
Table 4. Statistical parameters according to Friedman's test - the existence of differences in the degree of importance of professional competences between the group of motivated teachers for evaluation (group $M$ ) and the group of other teachers (Group $D-O$ ).

\begin{tabular}{cc}
\hline Compared groups & M / others \\
\hline $\mathrm{N}$ & 730 \\
$\chi^{2}$ & 3371.78 \\
$\mathrm{df}$ & 10 \\
$\mathrm{p}$ & $.0001^{* * *}$ \\
\hline
\end{tabular}

Statistical significance at the level $\alpha=.001(* * *)$

Furthermore, the research results identified which cases of $M$ in comparison to the group of other teachers $(D-O)$ was the degree of perception of professional competences significantly different. For this purpose, Man-Whitney U-test was used. Man-Whitney U-test, called Wilcoxon test, allowed us to test the hypothesis of a match between two distribution functions. Evaluation of the competence by teachers from the group $M$ - teachers motivated for evaluation by their authorities (selection 1) and point evaluation of the same competence by other teachers from the groups $D-O$ (selection 2), wherein the number of values in view of the two selections were not be the same, probably. It was also the case in the current examination since there were not the same numbers of teachers who responded.

Table 5. Statistical parameters of perception of the degree of importance of different professional competences between teachers from the group $M$ and other groups of teachers according to Mann-Whitney test.

\begin{tabular}{lcccccccccc}
\hline $\begin{array}{l}\text { Observed profes- } \\
\text { sional competence }\end{array}$ & A & B & C & D & E & F & G & H & I & J \\
\hline Mann-Whitney U & 44403.0 & 41723.0 & 49824.0 & 50146.0 & 45981.0 & 45993.5 & 47245.5 & 48384.0 & 47255.5 & 47942.0 \\
Wilcoxon W & 62931.0 & 60251.0 & 68352.0 & 68674.0 & 64509.0 & 64521.5 & 65773.5 & 66912.0 & 65783.5 & 66470.0 \\
Z & -3.169 & -4.279 & -.896 & -.799 & -2.407 & -3.054 & -2.182 & -1.566 & -1.912 & -1.851 \\
p (2-tailed) & $.002^{* *}$ & $.0001^{* * *}$ & .370 & .424 & $.016^{*}$ & $.002^{* *}$ & $.029^{*}$ & .117 & .056 & .064 \\
\hline
\end{tabular}

Statistical significance at the level $\alpha=.05(*), \alpha=.01(* *), \alpha=.001(* * *)$

Table 5 displays the levels of statistical significance $\alpha=.001$, the hypothesis $\mathrm{H}_{0}$ was rejected in competence B, i.e. the teacher can identify the psychological and social factors of student's learning.

Further, table 5 shows that for the selected level of statistical significance $\alpha=.01$ the tested hypothesis $\mathrm{H}_{0}$ is rejected, i.e. the importance of the professional competences by teachers in the group $\mathrm{M}$ compared to other groups was perceived differently: A. can identify developmental and individual characteristics of students, F. is well aware of the content and methodology of the subjects taught. 
Eva STRANOVSKÁ, Mária LALINSKÁ, Ivana BOBOŇOVÁ. Teachers motivation towards assessment of their professional competences

PROBLEMS

OF EDUCATION

IN THE $21^{\text {st }}$ CENTURY

Vol. 76, No. 4, 2018

570 and in other groups was perceived differently: E. can plan and implement their own career development, G. can plan and design teaching / educational process.

\section{Discussion}

The results showed differences in various motivation categories: motivating, discouraging, unnecessary, unfair and other, with respect to professional competences. There was a significant difference found in the perception of the importance of teacher competences with respect to the group M (motivating) and other degrees of assessment perception. Most probably, those teachers who were motivated towards assessment attributed importance of assessment, or importance to other professional competences in the educational process higher than teachers, who considered assessment discouraging, unnecessary, unfair or other. There were also differences found in the perception of the importance of professional competences among teachers who viewed assessment as a discouraging element compared to the group of teachers who viewed assessment as unnecessary, unfair and other. Moreover, differences were found among the group of teachers who perceived the assessment as an unnecessary element compared to the teachers who perceived the assessment as unfair or other and among teachers who perceived the assessment as an unfair element compared to another motivational level. In this respect, the results correspond with Dörnyei (2014) who distinguishes the "ideal self" and "ought-to-self". While the "ideal self" is targeted at the voluntary achievement of the personal objective, "ought-to-self" is limited to their attribution to expectations of others and duties the person has to fulfil. The teachers whose the motivation system is based on "ought-to-self", their intentions are to "survive" the educational process; in relation to professional competences, they do not have any specific individual targets referring to the professional competences they consider important to develop. It can be said that intentionality appears to be an important factor that is closely related to motivation for assessing professional competences of teachers. Therefore, the model of Dörnyei assumes that motivation could be related to systematic, long-term and positive self-determination of the individual. In the context of given research systematic and positive self-determination is closely connected with motivation for assessment, therefore, the first level of teacher motivation - motivating for assessment of their professional competences, supports the perception of the importance of different professional competences in the educational process.

Then specific professional competences of the teacher motivated for assessment consider being important were examined, i.e. differences in the perception of the importance of different professional competences with respect to the first degree of motivation of teachers (teacher motivated). It was assumed, there are differences in the perception of the importance of competences A, B, C, and E. Except of the competence C, there were recorded the differences in the perception of the importance of competences A, B, E. It must be recall the fact that the recorded differences in perception of the degree of importance of different competences manifested when comparing the group of teachers who perceive their assessment by superiors as motivating with regard to all other groups of teachers (who see their assessment by superiors as discouraging, unnecessary, unfair or other).

Most notable differences can be observed at the level of statistical significance $\alpha=.001(* * *)$ with respect to assessing the degree of the importance of the competence B. teacher can identify the psychological and social factors of students learning. This phenomenon was even anticipated. This may be connected with the theory of interaction of motivation and success (Riemer, 2010), whether the individual is motivated by success or motivation leads to the success of the individual. In given research, it was proved that if the teacher can identify psychological and social factors of student's learning, he/she is motivated for assessment of his/ her professional competences; and vice versa, if the teachers are motivated towards assessment, 
they consider being important to identify the psychological and social factors of student's learning. To identify psychological and social factors of student's learning is not a simple matter, because during the process of measurement of learning outcomes latent factors enter into the process. In addition to the fundamental factors that affect overall performance of students, such as their abilities, difficulties and discriminatory features of the measurement tool, here also gender of student/investigator, student's social status, a variety of learning disabilities and behavioral disorders are possibly incorporated. Not all teachers are so conscious to be willing to disregard and break away from the objective assessment results expressed, for example, in test score, or other forms of measurement and evaluation. Therefore, such teachers who seek enhancements often need feedback from their authorities and find it supporting and motivating element for their professional progress and development.

Statistical significance $\alpha=.01(* *)$ was found out. There were differences among the groups of teachers motivated by assessment of competences and the other groups there were differences found in the perception of the degree of importance of such competences: A. can identify developmental and individual characteristics of students and F. is well aware of the content and methodology of the subjects taught. Therefore, the assumption about the divergence of the perception of the degree of importance of competence A was confirmed. The identification of the developmental characteristics and individual differences between learners undoubtedly falls within the competences of a conscious modern educator. There is no need to perceive the word "modern" as a fad of the current understanding of new trends in education, but as a timeless phenomenon, without which a healthy development of learner's potential cannot be achieved. In order to achieve the expected result, motivated teacher attributes importance to the observation of student and subsequent understanding of their individual differences (specifically, decentralized perception, emotional sensibility, and other). In this regard, the causal hypothesis of motivation is supported (Dörnyei, 2014; Riemer, 2010), while motivation influences result. The competence $\mathrm{F}$ has not been explicitly included into the research assumptions, because it is considered as a starting point, a basis, a kind of sine qua non of the complete educational activity of the teacher. Therefore, it is assumed that teachers at all levels of motivation (motivating, discouraging, unnecessary, unfair, and other) towards assessment would attribute importance to it. Table 1 describing the basic indicators of the described issues showed that the competence in the group M, which included more than two-thirds of the respondents, was assessed with the highest possible score among all other competences.

At the level of statistical significance $\alpha=.05$ (*) there were recorded differences in the following competences: E. teacher can plan and implement their own career development, and G. teacher can plan and design teaching/educational process. The difference in the perception of the degree of importance of the competence $\mathrm{E}$ with respect to the extent of motivation was also expected. To plan own professional development, but ultimately also educational process requires not only consciousness of teachers in relation to the perception of the meaning of their overall educational activities but also setting realistic goals and means leading to their achievements. This result supports the resultative hypothesis of motivation (Dörnyei, 2014; Riemer, 2010), the teachers focus on an outcome that motivates them to performance (positive assessment by authorities motivates them for continuous professional development). Moreover, this finding also shows systematic positive self-determination of the individual and their good managerial skills.

It is now possible to apply for many life-long oriented professional courses and seminars especially emphasizing development of teacher's management skills (e.g. De Wever et al., 2016; Kuhn, et al., 2016; and others), both, in terms of their personal professional development, but also designing their teaching activities. A teacher, who perceives this competence as an important one, is the teacher who needs feedback from his/her authorities.

Furthermore, the obtained results regarding competence $\mathrm{C}$ can develop student's personality and their competences showed assumed differences in the perception of the degree of importance as to the motivating factor towards assessment of teachers by their authorities. It 
Eva STRANOVSKÁ, Mária LALINSKÁ, Ivana BOBOŇOVÁ. Teachers motivation towards assessment of their professional competences

PROBLEMS

OF EDUCATION

IN THE $21^{\text {st }}$ CENTURY

Vol. 76 , No. 4, 2018

572

was not confirmed. There are several reasons for such results. This competence is a phenomenon, which is probably closely related to the nature of the professional competences A and $\mathrm{B}$. In this respect, teachers view such competence as a vague, as an issue, for which they are not responsible, it is out of their reach. There is a huge variety of contexts, with which a student comes into contact since they were born. Thus, teachers may feel helpless in terms of having an impact on students' developmental process and overall enhancement.

\section{Conclusions}

The research showed that motivation towards being assessed shows to be one of the crucial indicators of the quality of the educational process. Teachers motivated towards assessment ascribed importance to competences oriented towards the students, to competences oriented towards the educational process and the competence oriented towards self-development of the teacher, whilst competences oriented towards the student and towards developing the personality of a student dominated. This research contributed to prove the importance of motivation in the process of developing the professional competences of a teacher regarding the perception of how important these competences are in the educational process. The research further confirmed the synergy between the causal and resultative motivational hypotheses. The assessment of teacher by their superiors leads to heightened motivation and the motivation towards assessment leads the teacher to an effort of increasing his/her success in the educational process. These findings will contribute to creating a higher quality teacher's professional competence measuring tool, which the Slovak educational context noticeably lacks. The research introduces further questions of study: finding out the reasons of motivation and demotivation towards assessment, what are the ways to motivate teachers towards the assessment of their professional competences so that it is perceived by them as an incentive for their professional growth and success in forming the performance and personality of a student.

\section{Acknowledgements}

This work was supported by the Slovak Research and Development Agency under the contract No. APVV-14-0446.

\section{References}

Bagalová, L'. (2011). Pedagogické inovácie z pohl'adu učitel’a a riaditel'a [Educational innovation from the view of teacher and director]. Bratislava: Statpedu.

Blömeke, S., Bremerich-Vos, A., Haudeck, H., Kaiser, G., Nold, G., Schwippert, K., \& Willenberg, H. (2011). Kompetenzen von Lehramtsstudierenden in gering strukturierten Domänen. Erste Ergebnisse aus TEDS-LT [Teacher education and development study: Learning to teach TEDSLT]. Münster: Waxmann.

Čeretková, S., Boboňová, I., Markechová, D., \& Tirpáková, A. (2016). Hodnotenie kompetencií učitel’a [Evaluation of teacher's competences]. In T. Zdráhal \& E. Nováková (Eds.), EME 2016 (pp. 263270). Olomouc: Upol.

De Wever, B., Vanderlinde, R., Tuytens, M., \& Aelterman, A. (2016). Professional learning in education: Challenges for teacher educators, teachers and student teachers. Gent: Academia Press.

Dörnyei, Z. (2014). Motivation in second language learning. In M. Celce-Murcia, D. M. Brinton \& M. A. Snow (Eds.), Teaching English as a second or foreign language 2014 (pp. 518-531). Boston, MA: National Geographic Learning/Cengage Learning.

European Commission. (2012). Supporting the teaching professions for better learning outcomes. Accompanying the document communication from the commission rethinking education: Investing in skills for better socio-economic outcomes. Retrieved from http://ec.europa.eu/education/news/ rethinking/sw374_en.pdf. 
Fandelová, E., Gadušová, Z., \& Lomnický, I. (2016). Head teacher's perception of teacher's oral and written assessment. In I. Benešová \& J. Brožek (Eds.), Efficiency and responsibility in education 2016 (pp. 113-120). Prague: Czech University of Life Sciences.

Frey, A. (2006). Methoden und Instrumente zur Diagnose beruflicher Kompetenzen von Lehrkräften [Methods and instruments for the professional teachers competence evaluation]. Zeitschrift für Pädagogik, 51, 30-46.

Fritsch, S., Berger, S., Seifried, J., Bouley, F., Wuttke, E., Schnick-Vollmer, K., \& Schmitz, B. (2015). The impact of university teacher training on prospective teachers' CK and PCK - a comparison between Austria and Germany. Empirical Research in Vocational Education and Training, 7 (4), 1-20. doi:10.1186/s40461-015-0014-8.

Gadušová, Z., \& Hašková, A. (2016). Evaluation of teachers' competences as a part of school leadership. International Conference on Communication, Business and Education 2016, 7-12. doi:.5729/ lnms.vol50.7.

Gadušová, Z., \& Vítečková, M. (2015). Vysokoškolské studium učitelství z pohledu začínajícího učitele a identifikace jeho problematických oblastí [Newly qualified teachers' perception of university teacher training and identification of its problem areas]. Edukácia, 1 (1), 266-275.

Gadušová, Z., Hockicková, B., Lomnický, I., Predanocyová, L., \& Žilová, R. (2016). Evaluation of teachers' competences. In A. L. Martínez \& L. G. Chova (Eds.), The 10th International Technology, Education and Development Conference 2016 (pp. 6957-6965). Valencia: IATED Academy.

Gardner, R. C. (1985). Social psychology and second language learning: The role of attitudes and motivation. London: Edward Arnold.

Gold, B., \& Holodynski, M. (2015). Development and construct validation of a situational judgment test of strategic knowledge of classroom management in elementary schools. Educational Assessment, 20 (3), 226-248. doi:org/10.1080/10627197.2015.1062087.

González, I., \& López, I. (2010). Validación y Propuesta de un Modelo de Indicadores de Evaluación de la Calidad en el la Universidad [Validation and proposal of a model of the quality evaluation indicators at the university]. Revista Iberoamericana de Educación, 53 (6), 1-13.

Kirchner, K. (2004). Motivation beim Fremdsprachenerwerb. Eine qualitative Pilotsudie zur Motivation schwedischer Deutschlerner [Motivation to learning foreign languages. A qualitative pilot study about motivation of Swedish German students]. Zeitschrift für Interkulturellen Fremdsprachenunterricht, 9 (2), 1-32.

Kleickmann, T., Richter, D., Kunter, M., Elsner, J., Besser, M., Krauss, S., \& Baumert, J. (2013). Teachers' content knowledge and pedagogical content knowledge: The role of structural differences in teacher education. Journal of Teacher Education, 64 (1), 90-106. doi:10.1177/0022487112460398.

Kuhn, Ch., Alonzo, A. C., \& Zlatkin-Troitschanskaia, O. (2016). Evaluating the pedagogical content knowledge of pre- and in-service teachers of business and economics to ensure quality of classroom practice in vocational education and training. Empirical Research in Vocational Education and Training, 8 (5), 1-18. doi:10.1186/s40461-016-0031-2.

Liepa, D., Dudkina, A., \& Sile, M. (2012). Self-assessment criteria of teacher's well-being. Problems of Education in the 21 $1^{\text {st }}$ Century, 48, 81-90.

Lukas, J. F., Santiago, K., Etxeberria, J., \& Lizasoain, L. (2014). Adapting to the European higher education area a questionnaire on student opinion about the teaching of lecturers. Revista Electrónica de Investigación y Evaluación Educativa, 20 (1), 1-20. doi:10.7203/relieve.20.1.3812.

Magová, L., Bad’ová, P., Boboňová, I., Csáky, A., Čeretková, S., Fandelová, E., ... Žilová, R. (2016). Hodnotenie kompetencii učitel'ov v európskom a slovenskom kontexte [Evaluation of teacher's competence in European and Slovak context]. Praha: Verbum.

Moreno-Murcia, J. A., Torregrosa, Y. S., \& Pedreño, N. B. (2015). Questionnaire evaluating teaching competencies in the university environment. Evaluation of teaching competencies in the university. Journal of New Approaches in Educational Research, 4 (1), 54-61. doi:org/10.7821/ naer.2015.1.106.

Pavlov, I. (2013). Štandardizácia profesijných kompetencii učitelov (východiská a perspektívy) [Standardization of professional teacher's competence (background and perspective)]. Prešov: Škola plus.

Philpott, C., Scott, H., \& Mercier, C. (2014). Initial teacher education in schools: A guide for practitioners. London: Sage Publications.

Recepoğlu, E. (2013). Investigating motivation of primary and secondary school teachers in terms of demografic variables according to teacher opinions: A case of Turkey. Problems of Education in the $21^{\text {st }}$ Century, 51, 104-112. 
Eva STRANOVSKÁ, Mária LALINSKÁ, Ivana BOBOŇOVÁ. Teachers motivation towards assessment of their professional competences

PROBLEMS

OF EDUCATION

IN THE $21^{\text {st }}$ CENTURY

Vol. 76, No. 4, 2018

574

Riemer, C. (2010). Motivation. In H. Barkowski \& H. J. Krumm (Eds.), Fachlexikon Deutsch als Fremdund Zweitsprache [German as a foreign language and as a second language]. Basel: Francke.

Šarniková, G. (2010). Podoby kompetencií v európskej a slovenskej edukačnej realite [Types of competence in European and Slovak educational reality]. In M. Karwatowska \& A. Siwiec (Eds.), Przeobrażenia w kulturze i edukacji na przełomie XX $i$ XXI wieku [Transformation in culture and education at the turn of the 20th and 21st centuries]. Lublin: Wydawnictwo Drukarnia.

Schleicher, A. (2012). Preparing teachers and developing school leaders for the 21st century, lessons from around the World. OECD Publishing.

Sokolová, L., Lemešová, M., \& Zacharová, Z. J. (2014). Psychologická príprava budúcich učitel'ov a učiteliek: Inovativne pristupy [Psychological preparation of future teachers: Innovative approaches]. Bratislava: UK.

Stranovská, E., Lalinská, M., \& Boboňová, I. (2017). Perception of the degree of importance of teachers professional competences from the perspective of teacher and head teacher in the evaluation process of educational efficiency. Pedagogy, 127 (3), 5-20. doi: 10.15823/p.2017.36.

Švarbová, E. (2012). Zastúpenie projektového vyučovania v cudzojazyčnej výučbe - klady a zápory [Representation of project teaching in foreign language teaching - pros and cons]. Didactique du FLE dans les pays slaves, 3 (1), 25-32.

Received: May 30, 2018

Accepted: August 05, 2018

\begin{tabular}{|ll|}
\hline Eva Stranovská & $\begin{array}{l}\text { Associate Professor, Constantine the Philosopher University, Faculty of Arts, } \\
\text { Department of German Studies, Sttefánikova 67, } 94974 \text { Nitra, Slovakia. } \\
\text { E-mail: estranovska@ukf.sk } \\
\text { Website: https://www.ukf.sk/en }\end{array}$ \\
\hline Mária Lalinská & $\begin{array}{l}\text { Researcher, Constantine the Philosopher University, Faculty of Arts, Depart- } \\
\text { ment of Romance Studies, Štefánikova 67, 949 74Nitra, Slovakia. } \\
\text { E-mail: mlalinska@ukf.sk } \\
\text { Website: https://www.ukf.sk/en }\end{array}$ \\
\hline Ivana Boboňová & $\begin{array}{l}\text { Researcher, Constantine the Philosopher University, Faculty of Natural Sci- } \\
\text { ences, Department of Mathematics, Tr. A. Hlinku 1, 949 74 Nitra, Slovakia. } \\
\text { E-mail: ibobonova@ukf.sk } \\
\text { Website: https://www.ukf.sk/en }\end{array}$ \\
\hline
\end{tabular}

